\title{
HUBUNGAN PENGETAHUAN DAN SIKAP TENTANG BENCANA BANJIR TERHADAP KESIAPSIAGAAN DALAM KESEHATAN PADA MASYARAKAT RW 05 RT 01 DAN RT 03 KELURAHAN GONDRONG KOTA TANGERANG
}

\author{
*Lindawati, *Wasludin
}

\begin{abstract}
Abstrak
Secara geografis Indonesia terletak pada wilayah yang rawan terhadap bencana alam seperti tanah longsor, gempa bumi, letusan gunung berapi dan banjir. Pemukiman masyarakat RW 05 RT 03 dan 01 Kelurahan Gondrong Kota Tangerang merupakan daerah yang paling parah bila terkena banjir karena berdampingan dengan sungai Angke yang bermuara dari daerah Bogor. Penelitian ini diharapkan dapat mengetahui hubungan pengetahuan dan sikap tentang bencana banjir dalam kesiapsiagaan dalam kesehatan pada masyarakat RW 05 RT 03 dan 01 Kelurahan Gondrong Kota Tangerang dengan menggunakan desain penelitian crosssectional. Jumlah responden sebanyak 60 orang. Analisis data dalam penelitian ini menggunakan uji chi-square. Hasil penelitian memperlihatkan bahwa responden yang berpengetahuan tinggi memiliki kesiapsiagaan yang siap dengan $p$ value 0,04 artinya ada hubungan antara pengetahuan dengan kesiapsiagaan dimana 38 orang berpengetahuan tinggi 27 orang ( $71 \%$ ) memiliki kesiapan dalam menghadapi banjir. OR 3,85 yang artinya orang berpengetahuan tinggi memiliki kesiapsiapsiagaan 4 kali dari orang yang berpengetahuan rendah.. Diharapkan bagi institusi pendidikan untuk membentuk satgas bencana banjir yang bekerjasama dengan BPBD dan masyarakat rawan banjir .
\end{abstract}

Kata kunci : Pengetahuan, Sikap, Bencana Banjir, Kesiapsiagaan dalam kesehatan

*Dosen Jurusan Keperawatan Poltekkes Kemenkes Banten 


\section{Latar Belakang}

Secara geografis Indonesia terletak pada wilayah yang rawan terhadap bencana alam seperti tanah longsor, gempa bumi, letusan gunung berapi dan banjir. Dari beberapa bencana tersebut banjir merupakan bencana yang sering datang dan merupakan kondisi yang tidak dapat dihindari di sejumlah daerah karena sekitar $30 \%$ dari 5000 sungai besar yang ada di Indonesia melintasi kawasan padat penduduk Presentase kejadian banjir di Indonesia mencapai $38 \%$ dari seluruh kejadian bencana. Kejadian longsor mencapai $18 \%$ dari seluruh kejadian bencana. (Bakornas PB.2007).

Adanya factor perubahan iklim, tata guna lahan dan kenaikan permukaan air laut seringkali menyebabkan banjir pada saat musim penghujan( Dewi, 2010). Risiko banjir tidak dapat dihindari sepenuhnya sehingga harus dikelola. Manajemen bencana banjir memang tidak berusaha untuk menghilangkan bahaya banjir tetapi untuk menanggulanginya. Risiko banjir tergantung pada komponen yang terdiri dari bahaya dan kerentanan. Kombinasi faktor alam dan manusia menciptakan risiko banjir (Ulum, 2013 ).

Banjir besar di wilayah DKI Jakarta secara rutin terjadi setiap 5 tahun dan semakin sering memakan korban jiwa. Tahun 2007 sedikitnya 80 orang dinyatakan tewas selama 10 hari karena terseret arus, tersengat listrik atau sakit. Kerugian material akibat matinya perputaran bisnis mencapai triliunan rupiah (Yulaelawati \& syihab, 2008). Menurut data BNPB, tahun 2013 jumlah korban mencapai 15 orang dengan lonjakan pengungsi mencapai 50.000 jiwa (BNPB, 2013).Saat ini di awal tahun 2016, hampir sebagian besar wilayah Indonesia dikepung oleh banjir besar dan tanah longsor.

Pemukiman masyarakat RW 05 RT 03 dan 01 merupakan daerah yang paling parah bila terkena banjir karena berdampingan dengan sungai Angke yang bermuara dari daerah Bogor. Banjir menyerang dan mengenangi rumah masyarakt bahkan sering datang tiba- tiba. Dampak banjir mengganggu kehidupan dan penghidupan masyarakat bahkan mengakibatkan timbulnya korban jiwa manusia, kerusakan lingkungan, kerugian harta benda, dan dampak psikologis.

Pemerintah membutuhkan masyarakat yang memiliki pengetahuan dan kesiapsiagaan dalam menghadapi suatu bencana untuk mengurangi risiko

terhadap bencana (Matsuda dan Okada, 2006). Pengetahuan terhadap bencana merupakan alasan utama seseorang untuk melakukan kegiatan perlindungan atau upaya kesiapsiagaan 
yang ada. Kesiapsiagaan menghadapi bencana merupakan suatu kondisi masyarakat yang baik secara individu maupun kelompok yang memiliki kemampuan untuk mengantisipasi kemungkinan terjadinya bencana di kemudian hari. Pengetahuan akan mempengaruhi sikap dan kepedulian masyarakat untuk siap dan siaga dalam mengantisipasi bencana, terutama bagi mereka yang bertempat tinggal di daerah yang rentan terhadap bencana alam melanda dan membuat masyarakat lebih siaga untuk mengantisipasi kemungkinan terjadinya bencana guna menghindari jatuhnya korban jiwa, kerugian harta benda, dan berubahnya tata kehidupan masyarakat di kemudian hari (Gregg et al., 2004; Perry dan Lindell, 2008; Sutton dan Tierney, 2006 dalam Dodon ). Kepala keluarga harus memiliki sikap positif (merespon, menghargai,dan bertanggung jawab) dalam kesiapsiagaan rumah tangga, sehingga dapat meminimalkan kerugian dan korban banjir.

Hasil penelitian Firmansyah, dkk (2014) menunjukkan ada hubungan pengetahuan dengan perilaku kesiapsiagaan terhadap bencana banjir dan longsor pada remaja usia 15-18 tahun di SMA Al-Hasan Kemiri Kecamatan Panti Kabupaten Jember, sedngkan Penelitian Muctar Efendi H,,dkk (2011 ) menunjukan adanya hubungan pengetahuan dan sikap terhadap kesiapsiagaan menghadapi banjir.

\section{Metoda}

Penelitian ini menggunakan desain penelitian cross-sectional, Sampel dalam penelitian ini berjumlah 60 orang (Kepala Keluarga) Analisis data dalam penelitian ini diolah dengan program statistik. Analisis bivariat untuk sampel berpasangan digunakan uji chi-square.

\section{Hasil}

Selama pengumpulan data yang dilakukan mulai bulan Maret sampai Nopember 2016.

Jumlah responden penelitian sebanyak 60 orang (kepala keluarga).

\section{Tabel 1}

Distribusi frekuensi pengetahuan responden tentang kesiapsiagaan banjir

\begin{tabular}{lcc}
\hline Pengetahuan & Frekuensi & $\%$ \\
\hline Rendah & 18 & 32,1 \\
\hline Tinggi & 38 & 67,9 \\
\hline \multicolumn{1}{c}{ Jumlah } & 56 & 100 \\
\hline
\end{tabular}

Tabel 1. diatas menunjukan bahwa frekuensi

pengetahuan responden sebagian besar tinggi yaitu $67,9 \%$

\section{Tabel 2}

Distribusi frekuensi sikap responden tentang kesiapsiagaan banjir

\begin{tabular}{lcc}
\hline Sikap & Frekuensi & $\%$ \\
\hline Baik & 21 & 37,5 \\
\hline Tidak Baik & 35 & 62,5 \\
\hline \multicolumn{1}{c}{ Jumlah } & 56 & 100 \\
\hline
\end{tabular}


Tabel 2. memperlihatkan responden yang memiliki sikap yang tidak baik sebanyak 21 orang $(37,5 \%)$

\section{Tabel 3}

Distribusi frekuensi kesiapsiagaan responden tentang kesiapsiagaan banjir

\begin{tabular}{lcc}
\hline Variabel & Frekuensi & Persentasi \\
\hline Tidak siap & 22 & 39,3 \\
\hline Siap & 34 & 60,7 \\
\hline JUMLAH & 56 & 100 \\
\hline
\end{tabular}

Tabel 3. menjelaskan kesiapsiagaan responden menghadapi banjir yaitu responden yang siap sebanyak 34 orang $(60,7 \%)$

Distribusi Frekuensi Hubungan Pengetahuan Responden Dengan Kesiapsiagaan Dalam Menghadapi Banjir Dapat Dilihat Pada Table Dibawah Ini .

\section{Tabel 4}

Distribusi frekuensi hubungan Pengetahuan responden dengan kesiapsiagaan dalam menghadapi banjir yang berpengetahuan baik dengan kesiapsiagaan

Distribusi frekuensi hubungan sikap responden dengan kesiapsiagaan dalam menghadapi banjir

\section{Tabel 5}

Distribusi frekuensi hubungan sikap responden dengan kesiapsiagaan dalam menghadapi banjir

\begin{tabular}{|c|c|c|c|c|c|c|}
\hline \multirow[b]{2}{*}{ Sikap } & \multicolumn{2}{|c|}{ Kesiapsiagaan } & \multicolumn{2}{|c|}{ Jumlah } & \multirow{2}{*}{$\begin{array}{c}\text { OR } \\
95 \% \\
\text { CI }\end{array}$} & \multirow{2}{*}{$\begin{array}{c}\text { P- } \\
\text { Value }\end{array}$} \\
\hline & $\begin{array}{l}\text { Tidak } \\
\text { siap }\end{array}$ & Siap & $\mathrm{F}$ & $\%$ & & \\
\hline Tidak baik & 10 & 11 & 21 & 37,5 & 1,74 & 0,48 \\
\hline Baik & 12 & 23 & 35 & 62,5 & $(0,57$ & \\
\hline Jumlah & 22 & 34 & 56 & 100 & $\begin{array}{c}- \\
5,26)\end{array}$ & \\
\hline
\end{tabular}

Tabel 5. Tabel di atas menjelaskan responden yang memiliki sikap yang baik sebanyak 35 orang $(62,5 \%)$, dimana 23 orang ( $66 \%$ ) memiliki kesiapan dalam menghadapi banjir. OR 1,74 yang artinya orang memiliki sikap baik akan siapsiaga 1 kali dari orang yang tidak baik sikapnya .

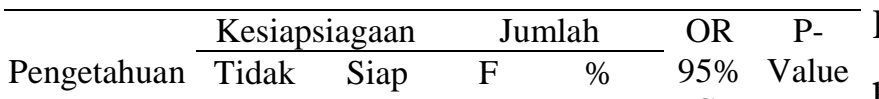

\begin{tabular}{ccccccc} 
& siap & & & & CI & \\
\hline Rendah & 11 & 7 & 18 & 32,1 & & 0,04 \\
Tinggi & 11 & 27 & 38 & 67,9 & 3,85 & \\
\cline { 1 - 5 } Jumlah & 22 & 34 & 56 & 100 & $(1,18-$ & \\
& & & & & & 12,18 \\
\hline
\end{tabular}
hubungan antara yang bersikap baik dengan kesiapsiagaan

\section{Pembahasan}

Tabel.4 menjelaskan responden yang Distribusi frekuensi pengetahuan berpengetahuan tinggi sebanyak 38 orang $(67 \%)$, dimana 27 orang ( $71 \%)$ memiliki kesiapan dalam menghadapi banjir. OR 3,85 yang artinya orang berpengetahuan tinggi tentang bencana banjir memiliki kesiapsiapsiagaan 4 kali dari orang yang tidak berpengetahuan tidak baik. $\mathrm{P}$ value 0,04 menunjukan ada hubungan antara masyarakat kelurahan gondrong RW 05 RT 01 dan 03 sebagian besar adalah berpengetahuan baik $67,9 \%$. Pengetahuan merupakan dasar bagi seseorang untuk melakukan kesiapsiagan dalam menghadapi banjir terutama pengetahuan tentang dampak banjir terhadap kesehatan dan tindakan untuk menghindari dampak 
banjir tersebut. Ada beberapa factor yang mempengaruhi pengetahuan antara lain pendidikan, pekerjaan, umur, minat, pengalaman, kebudayaan lingkungan sekitar, dan informasi ( Wahit Iqbal Mubarak, 2007 ). Responden pada penelitian ini sebagian besar berumur $<40$ tahun $(67,9 \%)$ yang merupakan kelompok usia dewasa muda yang pada umumnya memiliki pengetahuan yang tinggi karena biasanya bersumberkan dari berbagai media elektronik, media cetak ataupun social dan pada umumnya rentang usia ini juga memiliki memori yang kuat akan suatu objek misalnya dalam bidang bencana dan kesehatan sehingga menghasilkan pengetahuan yang baik. Responden sudah sering mengalami kebanjiran, bahkan banjir datang tiba- tiba tampa di awali hujan sehingga keadaan ini membuat responden sudah berpengalaman dalam menghadapi banjir yang akan meningkatkan pengetahuan. Begitu juga sebaliknya bila tidak ada pengalaman maka pengetahuan tersebuit akan mudah terlupakan (Iman Firmansyah,dkk,2014). Pengetahuan yang baik dan menghasilkan sikap yang baik.

\section{Distribusi frekuensi sikap} masyarakat dalam menghadapi bencana banjir termasuk baik (62,5\%). Sikap diartikan sebagai kesiapsiagaan mental, yang dipelajari dan di organisasi melalui pengalaman, dan mempunyai pengaruh tertentu atas cara tanggap seseorang terhadap orang lain, objek, dan situasi yang berhubungan dengannya (Gibson (1998). Sikap dalam menghadapi bencana banjir dan longsor merupakan salah satu indikator penilaian perilaku kesiapsiagaan. Kepala keluarga harus memiliki sikap positif (merespon, menghargai,dan bertanggung jawab) dalam kesiapsiagaan rumah tangga, sehingga dapat meminimalkan kerugian dan korban banjir. Salah satu factor yang menyebabkan orang bersikap baik bila memiliki pengetahuan baik atau tinggi yang pada akhirnya akan membuat warga memiliki kesiapsiagaan dalam menghadapi banjir. Disamping itu masyarakat sudah terbiasa dalam menghadapi banjir karena lokasi tempat itnggal mereka bersebelahan secara langsung dengan sungai Angke.

Kesiapsiagaan sangat penting dalam pencegahan pengurangan risiko bencana yang dilakukan sebelum suatu bencana terjadi dan bertujuan untuk meminimalkan efek samping bahaya melalui tindakan pencegahan yang efektif, tepat waktu, memadai, serta efesiensi untuk tindakan tanggap darurat dan bantuan saat bencana (Gregg 2004).. Upaya kesiapsiagaan juga bertujuan untuk memastikan bahwa sumber daya yang diperlukan untuk tanggap dalam peristiwa bencana dapat digunakan secara efektif pada saat bencana dan 
tahu bagaimana menggunakanya (Sutton dan Tierney, 2006). Ada beberapa tindakan yang dilakukan sebagai bentuk kesiapsiagaan saat bencana seperti menentukan prioritas barang-barang yang akan di bawah pada saat bencana terjadi, mematikan aliran listrik, melakukan pembagian tugas pada saat bencana terjadi, berlindung di tempat yang aman sampai ada pemberitahuan selanjutnya, menyepakati tempat evakuasi yang di laksanakan, meminta bantuan kepada tetangga, memberikan bantuan kepada tetangga,. Dari hasil penelitian diketahui kesiapsiagaan masyarakat yang siap menghadapi banjir sebesar $60,7 \%$.

$$
\text { Hasil penelitian juga }
$$
memperlihatkan bahwa responden yang berpengetahuan tinggi memiliki kesiapsiagaan yang siap dengan $\mathrm{p}$ value 0,04 artinya ada hubungan antara pengetahuan dengan kesiapsiagaan dimana 38 orang berpengetahuan tinggi 27 orang ( $71 \%$ ) memiliki kesiapan dalam menghadapi banjir. OR 3,85 yang artinya orang berpengetahuan tinggi memiliki kesiapsiapsiagaan 4 kali dari orang yang berpengetahuan rendah .Adanya hubungan antara pengetahuan dan kesiapsiagaan sama dengan hasil penelitian Iman Firmansyah,dkk (2014), begitu juga hasil penelitian LIPI-UNESCO/ISDR (2006) tentang kesiapsiagaan masyarakat pedesaan Aceh menghadapi bencana, menunjukkan bahwa pengetahuan mempunyai pengaruh terhadap tingkat kesiapsiagaan. memperlihatkan adanya hubungan antara pengetahuan dengan kesiapsiagaan masyarakat menghadapi banjir.

Pada penelitian ini diketahui tidak adanya hubungan antara sikap dengan kesiapsiagaan dimana hasil $\mathrm{p}$ value 0,48 artinya tidak ada hubungan antara yang bersikap baik dengan kesiapsiagaan dengan OR 1,74 yang artinya orang memiliki sikap baik akan siapsiaga 1 kali dari orang yang tidak baik sikapnya. Adanya perbedaan dengan penelitian penelitian sebelumnya seperti Penelitian Muhtar E Harahap,(2011) dan Tri Wahyuningsih (2013 ) yang memperlihatkan hasil penelitian adanya hubungan antara sikap dengan kesiapsiagaan, hal ini disebabkan karena pengalaman masyarakat RW 05 RT 01 dan 03 Kelurahan gondrong yang sudah sering mendapat bencana banjir. Sementara itu penelitian Muhtar effendi dan Tri Wahyuningsih dilakukan pada masyarakat yang baru mengalami banjir sehingga memperlihatkan sikap yang tidak baik terhadap kesiapsiagaan banjir.

\section{Simpulan}

Berdasarkan hasil penelitian menunjukan adanya hubungan pengetahuan responden dengan kesiapsiagaan dalam menghadapi 
banjir dengan $\mathrm{p}$ value 0,04 dan $\mathrm{OR} 3,85$, namun tidak ada hubungan antara sikap dengan kesiapsiagaan dimana $\mathrm{p}$ value 0,48 dan OR 1,75

\section{Daftar Pustaka}

Ahmad Yani, ( 2013), Pengembangan Pusat Pelatihan Dan Simulasi Kejadian Bencana Alam Untuk Pendidikan Kebencanaan

Nasiona.lhttp://

file.upi.edu/Direktori / FPIPS / JUR._PEND._GEOGRAFI/1967081 21997021

Bakornas PB.2007. Pengenalan Karakteristik Bencana dan Upaya Mitigasinya di

Indonesia.Jakarta:Badan Nasional Penanggulangan Bencana

(BNPB, 2013). Governance dan Capacity Building dalam Manajemen Bencana Banjir di Indonesia, Jurnal Penanggulangan Bencana Volume 4 Nomor 2, November 2013

Dewi, ( 2010 ), Kesiapsiagaan Sumber Daya Manusia Kesehatan Dalam Penanggulangan Masalah Kesehatan Akibat Bencana Banjir Di Provinsi DKI Jakarta. Fakultas Kesehatan Masyarakat. Universitas Indonesia.

Dodon (2013), Indikator dan perilaku kesiapsiagaan masyarakat di permukiman padat penduduk dalam antisipasi berbagai fase bencana banjir, Jurnal Perencanaan Wilayah dan Kota, Vol. 24 No. 2, Agustus 2013, hlm.125 - 140

Ella Yullelawati, Usman Syihab. 2008. Mencedasi Bencana. Grasindo. Jakarta

Firmansyah, dkk (2014) Hubungan Pengetahuan dengan Perilaku Kesiapsiagaan dalam Menghadapi Bencana Banjir dan Longsor pada Remaja Usia 15-18 tahun di SMA AlHasan Kemiri Kecamatan Panti Kabupten Jember, Artikel Ilmiah Hasil Penelitian Mahasiswa 2014

Gibson (1998). Pengelolaan Bencana Terpadu :Banjir, Longsor, Kekeringan dan Tsunami.Yusuf Watampone Press. Jakarta.

Gissing, Andrew. 2002. Bussines In The Macleay Commercial Flood Damage Kempsey 2001. NSW Floodplain Management Conference Gregg, C. E., Houghton, B. F., Johnston, D. M., Paton, D., and Swanson, D. A. 2004. The Perception of Volcanic Risk in Kona Communities from Mauna Loa and Hualalai Volcanoes, Hawaiki. Journal of Volcanology and Geothermal Research, 130, 179-196. 
Harahap, Mukhtar Effendi, dkk ( 2011), Pengaruh Pengetahuan dan Sikap terhadap Kesiapsiagaan Masyarakat dalam Menghadapi benjana Banjir di Desa perkebunan Bukit Lawang Kec. Bahorok tahun 2011. Jurnal Ilmiah Keperawatan

Vol. 1, No. 1, Februari 2015

Matsuda, Yoko., Okada, Norio. (2006). Community Diagnosis for Sustainable Disaster Preaparedness. Journal of Natural Disaster Science, Kyoto University

Sutton,J and Tierney, K. 2006. Disaster Preparedness: Concepts, Guindance and Research. Colorado: University of Colorado.

Ulum, Mochamad Chazienul( 2013) . Governance dan Capacity Building dalam Management Bencana banjir di Indonesia, Jurnal Penanggulangan Bencana Vol. 4, No. 2 Tahun 2013. 